TANULMÁNYOK 2019/1. Bölcsészettudományi Kar, Újvidék

STUDIJE 2019/1. Filozofski fakultet, Novi Sad

STUDIES 2019/1. Faculty of Philosophy, Novi Sad

ETO: 130.2SPENGLER O.

ORIGINAL SCIENTIFIC PAPER

821.511.141MÁRAI S.

821.511.141KERTÉSZ I.

DOI: 10.19090/tm.2019.1.79-97

A kézirat leadásának időpontja: 2019. március 4.

Az elfogadás időpontja: 2019. március 14.

\author{
BARCSI Tamás \\ Pécsi Tudományegyetem \\ Állam- és Jogtudományi Kar \\ Jogbölcseleti és Társadalomelméleti Tanszék \\ Pécs, Magyarország \\ barcsi48@gmail.com \\ NÉMETH Ákos \\ Magyar Nemzeti Levéltár Baranya Megyei Levéltára \\ Pécs, Magyarország \\ nemeth.akos@hotmail.hu
}

\title{
OSWALD SPENGLER HATÁSA MÁRAI SÁNDOR ÉS KERTÉSZ IMRE CIVILIZÁCIÓÉRTELMEZÉSÉRE
}

\author{
Uticaj Osvalda Špenglera \\ na interpretacije civilizacije u delima Šandora Maraija \\ i Imrea Kertesa
}

\section{The Influence of Oswald Spengler on the Civilization Interpretations of Sándor Márai and Imre Kertész}

Tanulmányunkban azt vizsgáljuk, hogy Oswald Spengler kultúra-, illetve civilizációértelmezése miként hatott két jelentős magyar író, Márai Sándor és Kertész Imre gondolkodására. Először bemutatjuk, hogy Márai különböző korszakokban keletkezett müveiben mennyiben érhető tetten a Spengler-hatás, miben ért egyet Márai Spenglerrel és miben vitatkozik vele. Ezt követően Kertész Imre konzervativizmusáról és Spenglernek A Nyugat alkonyában kifejtett felfogásával párhuzamba állítható megállapításairól lesz szó. Végül Márai és Kertész civilizációértelmezéseinek hasonlóságairól és különbségeiről írunk.

Kulcsszavak: Márai Sándor, Kertész Imre, Oswald Spengler, civilizáció 


\section{Bevezetés: A Spengler-hatás nyomában}

Jean-Jacques Rousseau, Karl Marx, Friedrich Nietzsche mellett aligha akad még egy alakja a modern kor filozófiatörténetének, aki olyan intenzív és széles körü hatást gyakorolt volna kora és az azt követö évtizedek szépirodalmára, mint Oswald Spengler. Az író Rousseau-val, a költő Nietzschével és a „kritikai realizmus" normarendszerét megalapozó Marxszal szemben a német történetfilozófus irodalmi hatása ugyanakkor korántsem tűnik magától értetődőnek. A szerző fö müve, A Nyugat alkonya (I. 1918, II. 1922) szentenciáit olvasva gyanítható, hogy maga Spengler sem vágyott ilyen babérokra: „... ha az új nemzedék tagjai, jelen könyv hatására, a líra helyett a technika, a festészet helyett a tengerészet és a megismeréskritika helyett a politika felé fordulnak, akkor szívem vágyát teljesítik; ennél jobbat az ember nem is kívánhat nekik" (Spengler 2011, I. 71) - szögezi le a gondolkodó, a humán müveltség és a művészetek hanyatlását vizionálva a civilizációs korszakába forduló nyugati „fausti” kultúrában.

Mi állhat e paradox jelenség hátterében? Mindenekelőtt a XX. század megmegújuló traumaélményei, illetve a jövővel kapcsolatos szorongásai, melyek időről időre felerősítették azt a fatalisztikus történetszemléletet, melynek leghatásosabb és legmódszeresebb kidolgozója Spengler volt. „Történelmi tájékozódást és filozófiai elmélyülést keresnek ma, a nagy földrengés után mindenütt, ahová elértek a világháború megrázkódtatásai. A mélyebb történelmi belátásért küzdő irodalom mint egy hatalmas tengely körül, Spengler történetfilozófiája körül kezd forogni” - állapítja meg szinte idejekorán a német filozófus történeti-relativista koncepciójának egyik legelső hazai ismertetője, Thienemann Tivadar (Thienemann 1922, 343). Ma már láthatjuk, hogy a válságba jutott nyugati civilizáció önreflexiója - Spengler várakozásaival ellentétben - épp a művészetben és az irodalomban csapódott le, többek között a korban népszerü negatív utópiák ( $\mathrm{H}$. G. Wells, George Orwell, Aldous Huxley), vagy az esszéisztikus, műfaji kereteket átlépő „fojtott hangú, önvizsgáló műfajok” (Paul Valéry, André Gide, José Ortega y Gasset, Salvador y Madariaga, Johan Huizinga) formájában (Cs. Szabó 1937b, 86). Ezek egyik legfontosabb inspirálójának a 20-as évek óta töretlenül a történelem spengleri víziója bizonyul.

$\mathrm{Az}$ irodalmi Spengler-recepció tehát hatásos cáfolatát jelenti a filozófus várakozásainak. E paradoxon végső eredője azonban magában Spengler nyelvében keresendő. „Földrengésből ocsúdtunk, arra figyeltünk legszívesebben, aki félrebeszélt vagy a pusztulást tanította. Írásmagyarázó gyülekezetet tartottunk az Elsodort Falu [sic!] fölött, Goethe helyett Spenglerből szedtünk német szavakat" - idézi fel másutt ifúsága nyugtalan éveit Cs. Szabó László, Spengler vonzerejének egyik legfontosabb tényezőjére, sajátos nyelviségére irányítva a 
figyelmet (Cs. Szabó 1937a, 18). Ennél is tovább megy A világirodalom történetét író Szerb Antal, aki egyenesen „az újabb német irodalom legnagyobb alkotásaként" méltatja a német filozófus szintézisét (Szerb [2000], 832). Állítása szerint Spengler érdeme nem kevesebb, minthogy ,a történelem egészét műalkotássá formálta, tökéletes szerkezetü épületté alakította az emberiség múltját, azt tette, ami csak a legnagyobb müvészeknek adatik meg: értelmet vitt az értelmetlenségbe" (Szerb [2000], 834).

A kultúra mint „szimbolikus formanyelv”, „a külső lét egészét megformáló stílus élettörténetének" (Spengler 2011, I. 80-81) tanulmányozása objektivációiban, mint (mü)tárgyakban, valamint a kultúraközi analógiák merész képzettársításai a történelem esztétikai szemléletének lehetőségét teremtették meg. Spengler asszociatív, gazdagon metaforikus nyelve a történelem konstrukciós jellegére, a historiográfiai szöveg fikciós narratívákhoz hasonló retorikus működésére irányítja a figyelmet, jó félszáz évvel előzve meg Hayden White elhíresült művét (White 1973).

„Spenglernek igaza van: a jó történetíró olyan, mint a költő: látomása van a világi cselekményröl. Az a történetírás, amely csak megállapít és csoportosít, nem ad képet az élményről, melynek tartalma az emberi sors az időkön át, halott törmelékeket rakosgat, címkéz, skatulyáz" - állapítja meg Márai Sándor (Márai 2006a, 18). A Cs. Szabó által felemlegetett válságműfajok, a „regényesszé, novella-esszé, kritika-esszé" (Cs. Szabó 1937b, 89) egyik leghatásosabb kortárs művelője Márai, legjelentősebb folytatóinak egyike pedig Kertész Imre volt. Tanulmányunkban e szerzők Oswald Spengler történetfilozófiájához füződő, ellentmondásoktól sem mentes viszonyát mutatjuk be, és a két író közötti szellemi kapcsolat néhány aspektusára is rámutatunk.

\section{Márai Sándor Spengler-olvasatai}

Spengler A Nyugat alkonyában nyolc, egymástól függetlenül létező kultúráról ír (de részletesebben csak a nyugati-fausti, az antik-apollóni és az arabmágikus kultúrával foglalkozik), amelyek nem hatnak egymásra lényegileg, de abban az értelemben „egyidejűek”, hogy azonos törvényszerűségeknek alávetve jönnek létre, teljesednek ki, öregednek el, hogy végül elpusztuljanak. Spengler civilizációnak a beteljesedett, megmerevedett kultúrát nevezi: „Mikor eléri célját, s az eszme, a benső lehetőségek teljes gazdagsága beteljesül, s megvalósul a külsőben, akkor a kultúra hirtelen megmerevedik, elsorvad, vére megalvad, erői megtörnek - civilizáció lesz belőle" (Spengler 2011, I. 160). A kultúra előtti népek az ősnépek, a civilizáció korszaka után pedig történetietlen fellah-népek élnek az egykori kultúrnépek helyén (Spengler 2011, II. 199, 200). A nyugati 
kultúra e teória szerint i. sz. 900 körül vette kezdetét, és a XIX. század elejétől Nyugaton a civilizációs időszakban vagyunk. A nyugati-fausti kultúra ősszimbóluma a határtalan tér, a fausti lélek pedig a határtalan tér meghódítására, a távolság legyőzésére törekszik.

Nem tudjuk, hogy az első világháború utáni éveket Németországban töltő fiatal Márai Sándor mikor találkozott először Oswald Spengler nagy visszhangot kiváltó téziseivel, azonban kortársaihoz hasonlóan a pályakezdő író esetében is a rátalálás élménye lehetett a meghatározó. Márai visszaemlékezése szerint már gyerekkorát is a „valami nincs rendben” alapérzése hatotta át a „sürü, ferencjózsefi béke" utolsó éveiben (Márai 2000, 40, 47). Később a háború utáni évek válságélménye előzte meg a spengleri teóriával való találkozást: „Úgy féltem, ahogy egy fiatal állat félhet a földrengés elött. Akkor nem olvastam még Spenglert s nem gyüjtöttem »elméleteket «” - írja az Egy polgár vallomásaiban (1934-1935), húszas évek eleji németországi élményeit felidézve (Márai 2004a, 229). A német kultúrfilozófus szemléletének a fiatal alkotó kibontakozó írásművészetére gyakorolt hatását ugyanakkor mi sem jelzi jobban, minthogy az Istenek nyomában (1927) című útirajzot Lőrinczy Huba egyenesen „irodalmunk első ízig-vérig spengleriánus alkotásának" nevezi (Lőrinczy 1997, 281).

A Spengler-hatás fő vonásai már a fiatal publicista közel-keleti útirajzában tetten érhetőek. Itt mutatkozik meg elsőként az a Spengler, illetve Frobenius műveiben gyökerező kultúrmorfológiai szemlélet, amely később annyira jellemző lesz Márai látásmódjára. Az európai utazó Egyiptomot és a Mediterráneumot a nagy kultúrák, mint saját formanyelvet hordozó társadalmi-szellemi alakzatok évezredek óta tartó felvonulásának színtereként írja le. A Spenglert idéző „hatalmas kultúrák sokaságának színjátéka” (Spengler 2011, I. 42-43) a kairói múzeumban kiállított ókori kincsek, azaz egy letünt arisztokrácia különleges igénnyel megformált használati tárgyainak bemutatása, vagy a pompeji ásatások során előkerült falfestmények jellemzése során is tetten érhető (Márai 2011, 64-67, 210). Mindezen tárgyakban, alkotásokban olyan szimbólumokat lát és láttat az elbeszélő, melyek általános érvénnyel képesek kifejezni az egyes kultúrák szellemét. A pompeji romok szemlélete a nietzschei-spengleri örök visszatérés és az egymást követő kultúrák homológiájának gondolatát is felidézi a narrátorban: „Az egész virágos, kosaras, fortunás cikornyát megtalálod Pompejiben, ahol valahogy minden a tizennyolcadik század végére emlékeztet. [...] minden megismétlődik és visszajön az időkben, lehet, hogy a láva is" (Márai 2011, 210). ${ }^{38}$

\footnotetext{
${ }^{38}$ „Egyidejűnek « nevezek két történelmi tényt, melyek - mindegyik a maga kultúráján belül - relatíve pontosan ugyanazon a helyen tünnek fel, és ennek megfelelően pontosan ugyanaz a jelentőségük. [...] ...egy kultúra történeti képében egyetlen olyan, mély fiziognómiai jelleget, jelentőséget hordozó jelenség sincs, melynek párját ne lehetne fellelni a többi kultúrában, mégpedig szigorúan jellemző formában és egészen meghatározott helyen" (Spengler 2011, I. 167, 168).
} 
„....a részben példázni az egészet, egy szemvillanásban az embert, az emberben a népet. Sokat ír egy képről, és ahogyan a képről ír, abban az egész képtár benne van” - jellemzi Márai elbeszélői módszerét Szabó Zoltán (Szabó 2001, 244). Mégsem lehet egyszerüen spengleriánusnak nevezni Márai szemléletét, hiszen az irónia mindenütt tetten érhető a kötet lapjain. A Goethe Faustjának egy gyürött példányával útra kelő, a nyugati világból mintegy disszidáló ifjú, aki később a nílusi alkonyatban magányosan álldogáló tevéket hasonlítja a Nyugat hanyatlását jósló filozófushoz, nyilvánvalóan az elfogadva-elutasítás eltúlzott gesztusaival reflektál kora közkeletű válságfilozófiájára. Az útirajz gazdagon metaforikus, lírai elbeszélői tónusával fittyet hány a pesszimista kultúrfilozófus kora fiatalságához címzett ,jótanácsára”, az ironikus viszonyulásnak azonban csak egyik oka Spengler nézeteinek irodalom-, illetve művészetellenes jellege. A kortársaihoz hasonlóan „neofrivol” huszonéves Márai általában szkepszissel viseltet mindenfajta monolitikus nagy elbeszélés iránt, amit legtömörebben a Palesztinában élő szamaritánusok egyikéhez címzett elképzelt monológjában összegez: „nem érdemes a betüért meghalni, szamaritánus, mert az igazság viszonylagos, s igazság, ha van, csak egy van, hogy élni kell, amíg és ahogy lehet" (Márai 2011, 127).

A fiatal, szkeptikus-ironikus szemléletű Márait megragadja Spengler kultúraelméletének relativizmusa ${ }^{39}$, hiszen utazása minduntalan az európai fogalmak viszonylagosságára ébreszti: „Kairó az első város Keleten, ahol a poggyászból sok mindent ki kell dobálni, amit Európából hoztál magaddal, s amit itt már nem használhatsz teljes occidentális értelemmel" (Márai 2011, 63). E tapasztalatok azonban Spenglerrel ellentétes következtetésekre vezetik az utazót, hiszen pontosan a kultúrák egyenrangúsága alapján utasítja el a filozófus által szükségszerünek tekintett gyarmatosítást: „nem lehet, mégsem lehet ésszel fölfogni és megérteni, hogy mi, európaiak mit művelünk a világban! Mi keresnivalója van itt a légiónak?" - teszi fel a kérdést a francia idegenlégió szíriai jelenlétének nyomait szemlélve (Márai 2011, 167). Márai Spenglerhez hasonlóan vallja az egyén kulturális meghatározottságát, ez azonban nem korlátozza a kultúraközi érintkezések, határhelyzetek iránti érzékenységét. Ez utóbbira a háború után francia tulajdonba került egykori német kivándorlóhajó, fedélzetén a németből franciává lett elzászi pincérrel, vagy a keleti metropoliszok kulturális hibriditásának alakzatai nyújtanak példát: „minden hamis és meghamisított, ami még tiszta Kelet, abba is belerágta magát egy lélektelen civilizáció, s ami európai, azt elszennyezte a Kelet" (Márai 2011,29-30). Jellemző, hogy Márai a végső soron szintén a maga nagy elbeszélését létrehozó kulturális relativizmusnak sem

\footnotetext{
${ }^{39}$ „Nincsenek örök igazságok. Minden egyes filozófia korának és csakis saját korának kifejeződése, és nincs két olyan korszak, melynek filozófiai szándékai teljesen azonosak volnának” (Spengler 2011, I. 72).
} 
tulajdonít abszolút érvényt. Az életet, az önmagát igazoló „nagy szenvedélyt” és „egy nekikeseredett ifúság minden meggyőződésével” a mindenkit megillető emberi jogokat és méltóságot, mint az emberi lét „végső szükségességeit” tiszteli (Márai 2011, 102-103).

$\mathrm{Az}$ Istenek nyomában Spengler-recepciója mindezek alapján - némiképp talán paradox módon - jellemzően liberális karakterü, mindenekelőtt a kulturális pluralizmus elfogadásának és az Európa-központú világkép elutasításának irányát jelezve a fiatal Márai gondolkodásában. Az író naplóbejegyzései és önéletrajzi műveinek megjegyzései ugyanakkor arról tanúskodnak, hogy hosszú élete során vissza-visszatérő olvasmánya volt a német kultúrfilozófus műve, $s$ a vele való számvetést mindig jelenkorának eseményei inspirálták. Joggal merülhet fel a kérdés, miként változott Márai Spengler-élménye az évtizedek során, illetve milyen szerepet játszott az író konzervativizmusának elmélyülésében?

„Milyen szerencse, gondolom, hogy nemrégen olvastam újra Spenglert” állapítja meg a Napnyugati őrjárat (1936) narrátora, utalva rá, hogy a 30-as évek társadalmi és világpolitikai változásainak horizontjáról a német kultúrideológus pesszimista jóslata új értelmet nyer (Márai 2004b, 11). A címadás által is A Nyugat alkonyára reflektáló útirajz elbeszélőjének iróniája néhol tán még a korábbinál is élesebb: „Napnyugatra megyünk, a régi kultúra országaiba; mindenesetre viszek magammal szappant, hőmérőt, zsebkést s minden más apró használati tárgyat is, mert utolsó időben sokat olvastam a napnyugati birodalom hanyatlásáról, s telítve vagyok gyanakvással" (Márai 2004b, 11). Mindeközben azt is leszögezi, hogy „a könyv sokkal időszerübb ma, mint volt tíz év előtt, mikor először akadtam össze vele, a könyv átkozottul aktuális, adatait nem tudom cáfolni többé, következtetései félelmesek, valószínűek" (Márai 2004b, 11). A francia és a brit társadalom 30-as évekbeli válságjelenségeinek felmérésére vállalkozó utas a civilizációba merevedő kultúrák szinte minden jelenségét diagnosztizálja (tömegesedés, életritmus felgyorsulása, metropoliszok kialakulása). Márai a civilizáció időpánikjának jelképét látja a Tour de Suisse-győztes kerékpárversenyzőben és a Párizs felé száguldó expresszvonatban egyaránt, de a Champs Elysées-n nyolcas sorokban „rohamra induló” tankszerü, áramvonalas autókat szemlélve és az üzemszerűvé váló párizsi kisvendéglőkben járva is ez az érzés kísérti. Jóval többről van azonban szó a spengleri tételek felmondásánál, hiszen a mű valójában Márai távolodását jelzi a relativista állásponttól. Az elbeszélő továbbra sem fukarkodik a kulturális különbségekre, mint a megismerhetőség korlátjaira vonatkozó ironikus reflexiókkal. Ezt példázzák az Albany street szürke munkásházai, az angol ételek, az angol orvosok, az oxfordi ,jellemgyár”, sőt a londoni állatkert jól nevelt, illedelmes ,, angol majmai” is, melyek mind idegenül hatnak az utazóra. A nemzedékek által felépített európai polgári műveltségnek 
és a nyugati ember által kivívott szabadságnak azonban olyan egyetemes értéket tulajdonít, amely nem kor- és helyfüggö, ezért a válságtünetek megítélése is más. A nyugati életforma változásaival szembeni kritikai attitüd a Spengler által szükségszerünek, elkerülhetetlennek tekintett folyamattal való szembeszegülést fejezi ki: „Hinni akarok Nyugatban, az értelemben, a civilizáció önfegyelmező erejében" - szögezi le (Márai 2004b, 26). A ciklikus történelemkép és a nyugati kultúra eszkatológiájának nietzschei-spengleri igenlése helyett Márai analízise a folyamat be nem teljesedésére, vagy legalábbis késleltethetô voltára keres bizonyítékokat: „Nem hiszek Spenglernek [...]. Európa, amelyet Spengler temetget, ezer életjellel szól még hozzám. Nem hiszek a nyugati kapitalizmus mai formájában, de hiszek abban, hogy ez a kapitalizmus ki tud még termelni új életformákat" (Márai 2004b, 27). Az író nézőpontja e tekintetben a német kultúrfilozófussal szemben sokkal inkább az évtized kultúrkritikai esszéirodalmával mutat rokon vonásokat. ${ }^{40}$

„A pillanat, amelyet láttunk, nem éppen lelkesítö, de kétségbeesésre nincsen ok. Holnapra nem lesz vége a napnyugati müveltségnek, $s$ bástyáival, hadihajóival, irodalmával és társadalmi megegyezéseivel megmarad talán holnaputánra is" - összegez útirajza zárlatában az elbeszélő (Márai 2004b, 143). Az írói identitás pozicionálása ekkor már az értékőrzés jegyében áll, melynek legtömörebb összefoglalása az Egy polgár vallomásai zárlatában olvasható:

$\mathrm{S}$ utolsó pillanatig, amíg a betüt leírnom engedik, tanúskodni fogok erről: hogy volt egy kor és élt néhány nemzedék, amely az értelem diadalát hirdette az ösztönök felett, $s$ hitt a szellem ellenálló erejében, amely fékezni tudja a csorda halálvágyát. [...] Minden, amit tudok, annyi, hogy e tanulsághoz, a magam kegyetlen-hütlen módján, hüséges akarok maradni (Márai 2004a, 413).

A Márai által a 30-as évek során kialakított müfajtípusok: a szellemi ôrjáratról számot adó útirajz, vagy a „jelenkori történetírás”, melyre a patinás hírü Pesti Hírlapban publikált Vasárnapi krónika (1936-1943) cikkei nyújthatnak példát, egyfajta összeurópai horizontú írói magatartást képviselnek a kor pusztító folyamataival szemben. ${ }^{41}$ „Baljós bölcsek jósolták pusztulásodat, Napnyugati

\footnotetext{
${ }^{40}$ „Amíg Nietzschénél és Spenglernél a történelem átértékelése, a kultúrfolyamatok újratagolása és a küszöbönálló eszkaton fenyegetése az apokalipszis sürgetésébe és az eszkatológiai folyamat végtelen ismétlődésébe torkollik, és ebben az egyszerre tragikus és felszabadító periodikusságban keres gyógyírt, addig a 20-as, 30-as évek történetfilozófusai és moralistái [mindenekelőtt Julien Benda, José Ortega y Gasset, illetve Johan Huizinga - N. Á.] már többnyire az eszkatológiai processzus fékezésére, a folyamat eltérítésére törekednek" (Margittai 2005, 64).

${ }^{41}$ „E cikkek írója a megjelenés pillanatában nem tudta, hogy - a maga módján, a közíró szerény és közvetlen eszközeivel - történelmet is ír" (Márai 2006c, 5).
} 
Birodalom, Európa. [...] De ez csak egyik arcod volt, Európa. A másik, az örök, melyet szívemben őrzök, nagyszerü és emberi” - írja Márai a második világháború kitörésekor, elutasítva a spengleri jóslatot (Márai 2006c, 10).

Márai következő, kései önéletrajzi művében is megörökített Spengler-újraolvasására 1945 januárjában, a szovjet megszállás történelmi pillanatában került sor. „Máskor is, akkor is tapasztaltam, hogy az élet válságos helyzeteiben egy láthatatlan kéz sorsszerü válogatással adja kezünkbe az olvasmányt, amely - így vagy úgy, néha vargabetűvel - válaszol a pillanat problémáira. Valahogy ez történt most is, a különös hetekben, amikor újraolvastam Spengler nagy pesszimista könyvét" - állapítja meg az emlékíró (Márai 2006b, 103). Még ha a visszaemlékezés alapján kissé színpadiasan is hatna a házukban elszállásolt orosz katonák szomszédságában A Nyugat alkonyát olvasó szerző alakja, Márai 1945-ös Naplója megerősíti, hogy ezekben a hetekben csakugyan a német történetfilozófus műve jelentette egyik legfontosabb olvasmányát: „Spenglert olvasom, tizenöt év után másodszor. Időszerü" - szögezi le lakonikus tömörséggel (Márai 2006a, 7). Az ostrom heteit hozzátartozóival egy leányfalusi villában átvészelő író már a civilizáció végső fázisára jellemző, Spengler által jövendölt „télkorszak” beköszöntét látja az imperialista birodalmak háborújában (Márai 2006a, 12). A történetfilozófusra vonatkozó ítéletei azonban inkább elutasítóak: a történetírás Spengler által képviselt, elbeszélésszerűséget a középpontba helyező, „látomásos” formáját alapvetően pozitívan ítéli meg (Márai 2006a, 18), ugyanakkor példáit önkényesnek (Márai 2006a, 21-22), stílusát két ízben is „,műkedvelőnek” nevezi (Márai 2006a, 27, 80). Ami ennél rosszabb, a „fausti lélek” meghatározásában félreérthetetlenül a náci ideológia elözményét látja: „A nácizmus köszönhet egy és mást Spenglernek" - állapítja meg (Márai 2006a, 39).

A Naplóból gyakran szóról szóra átvett mondatok, bekezdések jellemzik a Márai emigrációja idején már Amerikában publikált Föld, föld!... (1972) címü önéletrajzi elbeszélést. Az újabb vallomásos kötetre a válogatás, egyes, a naplóíró által feljegyzett motívumok, ötletek részletező kifejtése, kontextusba helyezése jellemző, ugyanakkor a Spenglerre vonatkozó ítélete nem változik: „nem maradt meggyőző emléke" róla, idézi fel a két világháború közötti benyomásait (Márai 2006b, 102). Márai az összeomlás tragikus pillanata felől nézve a német filozófiatörténetben is a nácizmus genealógiáját fedezi fel, melyben kitüntetett hely illeti Spengler fő művét: „a háttérben valahol Nietzsche súgott, még mélyebben, a teuton lélek homályában, Fichte suttogta veszedelmes igéit... és tíz év előtt Spengler könyve is segített a náciknak" (Márai 2006b, 102).

A Nyugat alkonya történetideológiájával szembeni kételyei mindezek ellenére nem akadályozzák Márait abban, hogy a kulturális idegenséggel való találkozásait némiképp spengleriánus módon beszélje el. Az oroszokban mindenekelőtt 
a Kelet, mint egy autonóm és a nyugatitól teljesen eltérö logikát követő történelmi-társadalmi alakzat képviselőit látja: „Akkor délután én, személy szerint, megéltem valamit, amihez hasonló "élménye « Európában addig csak kétszer volt úgynevezett »szellemi munkásnak«: a kilencedik században, amikor az arabok előretörtek Autunig és Poitiers-ig, s a tizenhatodik században, amikor a törökök elvándoroltak Györig és Erlauig. Tovább akkor sem engedték a Keletet Európában..." - idézi fel az első orosz katonával való sorsfordító találkozás élményét (Márai 2006b, 14, 21), történelmi távlatból igyekezve választ adni arra, vajon hogyan felel majd a Nyugat az arab és az oszmán-török utáni újabb „keleti világnézeti betörésre" (Márai 2006b, 23). Az oroszok idegenségének legfőbb okát Márai a személyiségtudatuk határozatlanságában fedezi fel (Márai 2006b, 106-108), melyben a keleti és nyugati identitásformák közti szakadékot pillantja meg; míg a jövevények jellemzésében civilizáció (civilizálatlanság) és kultúra (müveltségtisztelet) spengleri dichotómiája köszön vissza (Márai 2006b, 50-51). Az oroszok órák iránti érdeklődéséről elmélkedve (Márai 2006a, 8-9; 2006b, 41-42) szintén eljátszik a spengleri értelmezéssel, de nem tud egyértelmű választ adni a kérdésre, vajon csakugyan a gépi civilizáció elöretörése által kiváltott időérzék állhat-e mögötte, vagy jóval prózaibb okok: a hazai óragyártás kezdetleges mivolta, vagy a karórák magas csereértéke jelenti a fö motiváló tényezőt.

Márai Sándor írói munkásságára különösen jellemző, amint a nemzetközi krizeológia filozófiai, kultúrtörténeti nézőpontjait, vizsgálati aspektusait az irodalmi narráció eszközeivé formálja. Ennek során - mint Kakuszi B. Péter is megjegyezte - meghatározó a különböző eredetü: manni, nietzschei, spengleri (illetve ortegai, bendai) hatások összekapcsolódása (Kakuszi 2001, 15). Az író gondolkodásmódját jól jellemzi Szávai János az „iteráció” fogalmával (Szávai 2008, 7-19). A spengleri történetfilozófiához füződő kapcsolatának jellemzésére is ez a megközelítés tűnik a legalkalmasabbnak, hiszen csak az időről időre visszatérő újraolvasások, nézőpontváltások és egymásnak ellentmondó értékelések metszetében válhat láthatóvá az elbeszélő viszonya a saját korában népszerü filozófus téziseihez.

\section{Spengler és Kertész civilizációkritikájának összefüggései}

Kertész Imre olvasta A Nyugat alkonyát (az sem elképzelhetetlen, hogy Spengler más írásait is), és viszonylag sok, a müben megfogalmazott gondolatokkal párhuzamba állítható megállapítást találhatunk Kertész esszéiben és naplóiban, illetve nyilvánvaló, hogy Kertész rokonszenvezett a politikai konzervativizmussal. Saját politikai meggyőződéséről - miután megállapítja, hogy az utolsó totalitá- 
rius birodalom összeomlása után a politikai fogalmak kiüresedtek, kaotikussá váltak -, Kertész a következőket írja $A$ boldogtalan 20. század című esszéjében:

[...] zsidó vagyok, de alig ismerem a zsidó hagyományt, s távol áll tőlem a zsidó nacionalizmus; konzervatív meggyőződésűnek érzem magam, de politikailag a liberális oldalon állok; a demokrácia mellett teszem le a garast, noha nem hiszek az emberek egyenlöségében, vonakodom elfogadni a többségi elvet, és kifejezetten irtózom a tömegtől, a módtól, ahogyan a tömeget irányítják, kordában tartják és szórakoztatják, valamint a tömegben rejlő fenyegetéstől, mely alapjában veszélyezteti a mindenkori kevesek magasabb eszmeiségét, ami az értékeket mindig is létrehozta (Kertész 2001a, 26-27).

Spengler is úgy vélte, hogy a „mindenkori kevesek” hozzák létre az értékeket, arisztokratikus világfelfogását mutatja egyrészt, hogy A Nyugat alkonyában a „metafizikai taktusként”, „kozmikus-növényszerü életoldalként”, a „sors megérzett harmóniájaként" értett rassz főként a nemességben „jut kifejezésre" ${ }^{\text {"2 }}$ (Spengler 2011, II. 133, 195), koncepciója szerint a kultúra időszakát akkor váltja fel a civilizáció korszaka, amikor a nemesség helyett a polgárság szerepe válik meghatározóvá, de az értékek hanyatlása a „negyedik rend”, a tömeg megjelenésével veszi igazán kezdetét. Továbbá a Poroszság és szocializmusban egyfajta teljesítményalapú arisztokratikus szocializmust ír le ideális társadalmi berendezkedésként, amelyben mindenki az állam, az Egész, a közösség érdekeit szolgálja, és amely formailag monarchia, az uralkodó pedig az állam első szolgája (Spengler 2013a, 28-98). ${ }^{43} \mathrm{~A}$ döntés éveiben is a teljesítményalapú porosz államot tartja leginkább ideálisnak az adott civilizációs viszonyok között (Spengler 2013b, 295-307).

Bár Kertész Spengler említett államelméletére nem reagál és íróként, esszéistaként a saját politikai filozófiai nézeteit sem fejti ki részletesen, de könyvei ismerői számára egyértelmü, hogy Kertésznek a Spengler által ideálisnak tartott berendezkedés nem lehet szimpatikus, hiszen az egyéni szabadság megőrzését mindennél fontosabbnak tekintette, Spengler porosz szocializmusában pedig a szabadság a szolgálat szabadságát jelenti elsősorban. Kertész szerint is problematikus a siker- és pénzcentrikusság, de azokat a porosz értékeket sem fogadja el a feladat, a rang, az államért végzett hivatásként felfogott munka (az államban mindenki hivatalnokká válik) és a kötelesség -, amelyeket Spengler szembeállít

\footnotetext{
${ }^{42}$ Nagy művében Spengler tehát nem a biológiai-antropológiai rasszfogalmat használja, és kifejezetten elutasítja a rasszizmust, a fajgyülöletet (ami a metafizikai taktus megbicsaklásából fakad).

${ }^{43}$ Ez szemben áll az angol liberalizmussal éppúgy, mint a kommunizmussal.
} 
az „angol” eszményekkel. Ahogy Spengler, úgy Kertész sincs jó véleménnyel a tömegdemokráciáról, de mégis megőrzendőnek tartja a demokratikus politikai rendszert, nyilvánvalóan azért, mert az egyéni szabadság tiszteletben tartása a demokratikus keretek között biztosítható leginkább. Spengler politikai gondolkodóként elveti a liberális demokráciákat, ugyanakkor történelemfilozófusként a demokráciát (1800 és 2000 között) szükségszerünek tartja a civilizációs korszakban, amelyet szintén szükségszerüen a cezarizmus követ majd (2000 után), a XX. század diktatórikus tendenciái is ezt elölegezik meg (Spengler 2013b, 187-188). Persze ezen diktatórikus berendezkedések egy részére Spengler szimpátiával tekint, nem éppen a bolsevik rendszerre, de Mussolini erényeit kiemeli ${ }^{44}$, bár a fasizmusra is csak átmeneti jelenségként utal. A nemzetiszocialista mozgalommal és állammal, illetve Hitler személyével kapcsolatban komoly fenntartásai voltak. ${ }^{45}$ Kertész természetesen mind a bolsevik, mind a náci diktatúrát elutasítja, ugyanakkor a kétféle totalitarizmus eltéréseit is kiemeli. A kommunisták és a nácik is törvénysértést követtek el, semmibe vették az európai (a nyugati) civilizáció konszenzuálisan elfogadott morális normáit. Ez a törvény a felvilágosodás és az újkori forradalmak következményeképpen hozzátartozott a civilizáció „lényegét” megragadó elbeszélés szelleméhez, minden ezzel szembeni cselekedet, így a tevőleges antiszemitizmus is, botránynak számított. A nácizmus és a bolsevizmus különbsége abban áll Kertész szerint, hogy amíg a bolsevizmus (ideológiája szerint az elbeszélés szellemének beteljesítésére törekedve) a törvényt taktikai okok miatt törvénytelenül alkalmazta, addig a nácizmus kifejezetten szembeszállt az elbeszélés szellemével, és törvényen kívül helyezte a törvényt (Kertész 2001a, 45-59). Ugyanakkor mindkét totalitarizmus célja az ,individuum eltiprása" volt, tehát az, hogy az ember ne a saját sorsát élje (Kertész 2001a, 52).

A sors fogalma Spenglernél és Kertésznél is meghatározó fontosságú. Kertész ezt az önmeghatározás értelmében használja: a sorstalanság állapotában vagyunk akkor, ha „a ránk kirótt determinációnkat éljük végig valóságként”, és nem a szabadságunkból adódó saját sorsunkat (amely a tragédia lehetőségét hordozza) (Kertész 2001b, 18-19). Spengler a kauzalitással szembeállított sors alatt valamiféle irracionális, kozmikus életerőt ért, amely meghatározza az adott kultúrát, a sorseszmét a mechanikusan gondolkodó civilizált nagyvárosi ember veszíti szem elől (Csejtei-Juhász 2009, 101).

\footnotetext{
${ }^{44}$ „Mussolini nem pártvezér, jóllehet munkásvezér volt, hanem országának ura. [...] Mussolini mindenekelőtt államférfi, jéghideg és szkeptikus, realista, diplomatikus. Valóban egyedül kormányoz. Mindent lát - ez a legritkább képesség egy abszolút uralkodó esetében" (Spengler 2013b, 295).

${ }^{45}$ De azért pl. független tanácsadóként szívesen segítette volna a nácikat hatalomra jutásukat követően, végül belső emigrációban halt meg 1936-ban. Spenglernek a nemzetiszocializmushoz füződő viszonyáról részletesen lásd Csejtei-Juhász 2009, 361-373, 388-397).
} 
Kertész nem különbözteti meg írásaiban egyértelműen a kultúra és a civilizáció fogalmát, sokszor ezeket egymás szinonimáiként használja, de nézetei mégis közel vannak Spengler felfogásához: például egy helyen Kertész a kultúrát egy nagyobb közösség univerzális kreativitásaként definiálja, amely kreativitás kimerült Nyugaton, és ez lehetővé tette a nácik megjelenését (Kertész 2001a, 100).

Számos olyan utalást találhatunk Kertész esszéiben és naplóbejegyzéseiben, amelyek egyértelmüen magukon viselik Spengler hatását. A Valaki másban azt olvashatjuk: egy arctalan massza hömpölyög „egy még mindig Európának nevezett múzeumban", amelyben a művészeteknek, az irodalomnak már nincs sok jelentősége (Kertész 1997, 117). Kertész ír továbbá az értelem és az élet ellentétéről (Kertész 2001b, 132), az erő szerepéről (Kertész 2001b, 169; 2016, 96), illetve kifejezetten a nyugati kultúra hanyatlásáról (Kertész 1997, 117; 2001b, 335; 2017, 43-44, 225, 312), és mindarról, ami ezzel együtt jár, így a személyiség, a tehetség, az (alkotó)erő kulturális jelentőségének csökkenéséröl (pl. Kertész 2017, 95, 112, 124, 398), illetve a nagy művészet megszűnéséről (pl. Kertész 1997, 107, 117; 2001b, 237, 242, 317; 2017, 63, 112, 294). ${ }^{46}$

Spengler elmélete alapján a nácik tevékenységét beleilleszthetjük a Nyugat hanyatlási folyamatába, hiszen mondhatjuk azt, hogy a nácik is továbbviszik, illetve átértelmezik (a civilizáció mindig átértelmez - állítja Spengler) a nyugati kultúrát létrehozó fausti lélek alapvető jellemzőit, így a határtalan tér meghódítására való törekvést, az erő, az akarat, a tett kultuszát, a nagy tevőleges emberek úrmorálját. ${ }^{47}$ Spengler koncepciójában a kultúra elképzelhetetlen eszmények nélkül, viszont „a kései civilizációkban a legmeggyőzőbbnek tűnő eszme sem más valójában, mint a tisztán zoológiai hatalmi kérdések álcázására szolgáló maszk" (Spengler 2011, II. 62). Spengler nem érte meg a náci birodalom kiteljesedését, majd a bukását, és a holokausztot sem, de amit látott, egyre kevésbé tetszett neki, hiszen ő más keretek között gondolta el Németország civilizációs időszakát. A Poroszság és szocializmusból is kiderül, hogy a civilizációs körülményeket különbözőképpen lehet kihasználni, többféle civilizációs államberendezkedés lehetséges (lásd Anglia és Poroszország szembeállítását). Spengler úgy vélte, hogy Hitlerék útja nem a kívánatos út, pl. a náci párt tömegmozgalmi jellege, romanticizmusa és nem utolsósorban primitív antiszemitizmusa miatt. ${ }^{48}$

\footnotetext{
${ }^{46}$ Persze további bejegyzéseket is lehetne említeni. Kertész olykor közvetlenül hivatkozik Spenglerre (lásd pl. Kertész 2017, 41). Kertész a Gályanapló egyik bejegyzésében (Kertész 2001b, 193) bizonytalan abban, kinek a meglátása („talán Brandes?” - teszi fel a kérdést), hogy Tolsztoj Krisztust mond, de Marxra gondol. Ezt Spenglernél olvashatjuk (vö. Spengler 2011, II. 232).

${ }^{47}$ A fausti kultúra ősszimbóluma a határtalan tér, vö. Spengler 2011, I. 253, 421, 46.

${ }^{48}$ Erről részletesebben: Csejtei-Juhász 2009, 367-370.
} 
Kertész a nácikról írva egyaránt hangsúlyozza azt, hogy folytatói voltak egy kulturális hagyománynak, és hogy tevékenységüket egy adott civilizációs keretben fejtették $\mathrm{ki}^{49}$, de azt is, hogy a legalapvetőbb nyugati morális értékeket érvénytelenítették (lásd a már idézett megállapítást a törvény törvényen kívül helyezésérool), Kertész főként ilyen értelemben beszél a nácik kultúra- és civilizációellenességéről.

\section{„Ma mindenütt szégyen élni” - Márai és Kertész}

Márai Sándor és Kertész Imre egyaránt úgy vélte, hogy a fasisztoid diktatúrák kiépülése Európa szívében, majd a második világháború katasztrófája fordulópontot jelent a nyugati civilizáció történetében.

Márai a gyerekként, szülővárosában megélt építő, eleven kultúra felbomlásának kezdetét az első világháború határpontjához kapcsolta. A két háború között felgyorsult változások a technikai civilizáció előretörését és a fogyasztói társadalmak kialakulását eredményezték. A publicista és esszéíró már a 40-es években szembenéz a tömegkommunikáció megjelenésével, s vele együtt a társadalmi nyilvánosság átalakulásával, valamint az írókra nehezedő piaci viszonyok kényszerítő erejével. Mindezek következtében csökken az értelmiség befolyása ami azonban nem menti fel az írót egyéni felelőssége alól:

$\mathrm{Az}$ irodalom bünözött, mi, az írók bünöztünk, mikor nem voltunk elég hősiesek, s nem tudtunk ellentállani [sic!] az üzletnek, a gépiesedő ízlésnek, az olcsó élvezetvágynak, nem bélyegeztük meg idejében és minden alkalommal, mikor szemeink elé került, a hamisítást, nem tanítottuk meg az embereket, mi a különbség az álműveltség és a műveltség, az álirodalom és az irodalom, az üzlet és az alkotás között (Márai 2000, 79-80).

Az európai írók legtöbbje kiszolgálta a húszas évek könnyed ízlését, majd részigazságokra hivatkozva, a „kisebb rossz” jegyében türte a totalitárius rendszerek kiépülését, ezért őket is felelősség terheli a nyugati értékrend, életforma

\footnotetext{
${ }^{49}$ Kertész a regényeiben ezt a folytonosságot egyértelművé teszi: a nácik túlfokozott tekintélytiszteletét, a kapott parancs meg nem kérdőjelezését, a foglyok alkalmazkodását megalapozta a tekintélyelvű apa-kultúra (lásd erről a Kaddist, Kertész 2002b), a koncentrációs táborok rendje a civilizáció során kialakult felügyeleti technikák alkalmazására épült (ez nyilvánvalóvá válik a Sorstalanságban és a Kaddisban, Kertész 2002a; 2002b), és persze a hatékony megoldásokra törekvő modern ipari technika tette lehetővé a halálgyárak (a gázkamrával kombinált krematóriumok) létrehozását is. Ezekről a kérdésekről bővebben lásd Barcsi 2018. A kirekesztés, a diszkrimináció az emberi méltóság tiszteletére épülő civilizációs morál érvényessége mellett is jelen volt számos vonatkozásban a nyugati társadalmakban (nők, kisebbségek, fogyatékkal élők, homoszexuálisok stb.), a nácik tehát a kirekesztés kultúrájára is alapozhattak, „a diszkrimináció totalitárius formája pedig a tömeggyilkosság" - állapítja meg Kertész A Holocaust mint kultúra című írásában (Kertész 2001a, 83-84).
} 
bukásáért. Márai eközben számot vet a szellemi szabadság visszaszorulásának következményeivel. A diktatúrák cenzurális intézkedései vagy a piaci törvényeknek való megfelelés egyaránt paralizálóan hatnak a kultúrára: „Korokban, melyek szükségből vagy a szájas önkény parancsára ez eszméket megtagadják, rövidzárlat következik be a szellemi életben, a gondolkozás láthatára elsötétül” jelentette ki Ihlet és nemzedék (1943) címen publikált akadémiai székfoglalójában (Márai 1992, 22-23). Az író Naplójában a nyilvánosság előtt vállalt elmarasztaló ítéleteknél gyakran még súlyosabb véleményt fogalmaz meg: „a magyar emberi anyag silányabb, mint képzeltem. A magyar társadalom nem pusztul el, de emberöltők munkája kell hozzá, míg valamennyire visszakapcsolja életébe a müveltség fegyelmező öntudatát" - állapítja meg az 1945-ös év utolsó napján (Márai 2006a, 371). Márai az egyedüli megoldást az oktatásban, a „nemzetnevelésben" látja, mely alkalmas lehet a magyar társadalom demokratikus politikai kultúrájának előmozdítására (Márai 2008). Az író ugyanakkor hol több, hol kevesebb esélyét látja a békés átalakulásnak; ezzel párhuzamosan merül fel az emigráció gondolata a szerző müveiben. Az 1945 és 1948 közötti évek során e tekintetben ellentétes álláspontokkal találkozhatunk, melyekben hol a remény, hol a kétely erősebb. ${ }^{50} \mathrm{Az}$ emlékíró az elhatározás sorseseményszerü fordulópontját egy Goethe-idézethez köti, melynek nyomán rádöbben, hogy itthon nincs már lehetősége többé a polgári identitáshoz kapcsolódó saját sors megélésére. „Nem lehet saját sorsnak érezni, amikor felrobban egy atombomba, vagy egy diktatúra kimond egy társadalom felett egy maradi, ostoba ítéletet. Ezért el kell innen menni valahová, ahol - talán - egy ideig lehetséges megélni a saját sorsomat. Mert itt már csak számadat vagyok egy kategóriában” (Márai 2006b, 429).

Kertész Imre, a Gályanapló tanúsága szerint, a szocializmus évtizedeiben is gyakran olvasta Márai müveit. Kertész szellemi rokonaként tekintett Máraira, és „összetartozásuk” szimbolikus bizonyítékát látta Márai Naplójának egy 1944-es bejegyzésében. Márai Leányfaluból a Budapestre tartó HÉV-en utazott, és a vonat elhaladt a budakalászi téglagyár mellett, ahol az író látta az összegyüjtött zsidókat - az ifú Kertész Imrét is itt tartották fogva. Márai tisztában volt azzal, hogy a hétezer Pest környéki zsidót deportálni fogják. „Ő negyvennégy éves volt, én tizennégy. Látta a sárga csillagos gyereket a téglaszárító pajták közt; s tudta, amit ez a gyerek akkor nem tudott, hogy hamarosan elviszik Auschwitzba" -

\footnotetext{
${ }^{50}$ „De a megvetés, amely teljesen eltölt most, mikor megismertem a magyar társadalom igazi arcát, olyan, hogy ebből már nem tudok kigyógyulni. El kell menni innen” (Márai 2006a, 34). Illetve: „,...nem marad más tennivaló számomra, mint itt élni, a Rózsadombon vagy valamilyen más dombon, ahol magyarul beszélnek, ülni mint az ajándékba kapott pekingi faragás kínaija ül és olvas egy puszpángfa alatt. Ez a puszpángfa a magyar nyelv; s a magyar nyelv számomra egyértelmű a sorssal" (Márai 2008, 116-117).
} 
írja Kertész a Gályanaplóban, majd ezt a részt átveszi Márairól szóló, 2000-ben született esszéjébe is (Kertész 2001b, 319, illetve 2001a, 239). Kertész számára azért különösen fontos Márai, mert úgy véli, hogy az író azon kevesek közé tartozott, akik nem hárították el a felelősségvállalást, és magukat is bünösnek tekintették abban, hogy a két világháború közötti években megindult folyamatok szörnyüséges eseményekké fajulhattak: „Bünösök vagyunk, mert európaiak vagyunk, és eltürtük, hogy az európai ember tudatában megsemmisüljön a »humanizmus «" - idézi Kertész Márait (Kertész 2001a, 226). Kertész rámutat arra is, hogy Márai távozása Magyarországról, csakúgy mint korábban Thomas Manné Németországból, demonstratív vállalkozás volt, azonban Márai emigrációja nem váltotta ki „a nemzet csöndes szégyenét”, távozását magánügynek tekintették, illetve Márai a „karikatúraszerü” magyar polgárság összeomlásából nem emelhetett a Doktor Faustushoz hasonló „templomot” (Kertész 2001b, 141-143, illetve 2001a, 236). Kertész úgy gondolja, hogy a magyar polgárság „sosem tudta betölteni modernizáló, mérséklö és civilizáló funkcióját", Márai Sándor sorsában pedig ,a soha el nem következett polgári Magyarország reprezentációja bukott el" (Kertész 2001a, 236). A kudarc címü regényének alkotói időszaka alatt olvasta (újra?) Kertész az Egy polgár vallomásait - tudjuk meg a Gályanaplóból - és összevetette Márai művét készülő regényével: „A környezetrajz; hová is fajult ez $A$ kudarcban!", és némileg módosítva idézi Márai gondolatát: „Ma mindenütt szégyen élni” (Kertész 2001b, 144). ${ }^{51}$

Márairól és Kertészről egyaránt elmondható, hogy nem osztották Spengler szimpátiáját a XX. század bizonyos diktatórikus tendenciái iránt, illetve a diktatúrák kialakulásának történelmi szükségszerüségében sem hittek. Mindketten elutasították a totalitariánus berendezkedéseket, a személyes szabadságot alapvető értéknek tartották, Kertész Márai nagyságát elsősorban individuális függetlenségében látja (Kertész 2001b, 142). Márai 1948-ban emigrált az országból, Kertész pedig az ötvenes évek második felétől visszavonultan, egy kis lakásban írja a Kádár-korszakban szinte teljesen visszhangtalanul maradó műveit.

A háború után először külföldre utazó Márai csendesen nyugtázza az európai kultúra örök értékeinek továbbélését: „Az olaszok csatáját Mussolini vesztette el; de Michelangelo nyerte meg s Leonardo da Vinci és Dante. A többi nem számít" (Márai 2008, 80). Ugyanakkor azzal is szembe kell néznie, hogy a háború fizikai és szellemi pusztítása után Európa többé már nem a régi: „Valamit elra-

\footnotetext{
${ }^{51}$ Kertész nem jelöli meg a forrást, de feltehetően Márai 1943-44-es Naplójából veszi az idézetet, amelyet kissé módosítva közöl. Valószínűleg pontatlanságról és nem szándékosságról van szó, mégis érdekes és sokatmondó Kertész beszúrása („mindenütt”). Az eredeti szöveg: „Szégyen élni. Szégyen a napon járni. Szégyen élni” (Márai 1945, 114).
} 
boltak Európából a vad erők, melyek acélseprőkkel sepertek végig a városok és csataterek felett. Az emberek élnek, mert élni organikus lehetőség, Európában is. De az élet ihlet nélkül nem szerep, csak tenyészet. Európában nem csak a nemzedéknek, a földrésznek sincs közös ihlete többé" (Márai 2008, 110-111). A lerombolt épületeket, műemlékeket helyreállítják, a civilizáció mintegy „önjáró” módon tovább müködik, de az értékteremtő eleven kultúra, a polgári életforma, erkölcs visszaszorulóban van. A szerepét vesztett, helyét kereső Európa jelképét az utazó egy mitologikus jelenetet ábrázoló XVI. századi bronz szoborban véli felfedezni, melyet Mussolini egykori palotájában állítottak ki; címe Ratto d’Europa - azaz „Európa elrablása”. Ettől kezdve mindvégig küzd a testet öltött látomással, mely útja során mindenütt kísérti: „Elrabolták, igazán? Kik és mit? [...] Mindenekelőtt a hivatástudatot; azt a tudatos vagy ösztönös zsiger-meggyőződést, [...] hogy Európának, tehát e földrész lakóinak valamilyen küldetésféle megbízatásuk és szerepük van a világban, s ezt a megbízatást az európai sorstól kapták örökségbe" (Márai 2008, 110).

Kertész bizonytalan abban, hogy a holokauszt után még beszélhetünk-e egyáltalán nyugati civilizációról, vagy sem. Több értelmező rámutatott arra (erről lásd Barcsi 2018), hogy Kertész ellentmondásosan fogalmaz: olykor arról ír, hogy a nyugati civilizáció (illetve nyugati kultúrát is említ) túlélte a holokausztot, és mivel Auschwitz e civilizációban jött létre, ezért elsősorban ennek keretein belül kell reagálni Auschwitzra, olykor pedig azt állítja: Auschwitz elpusztította a nyugati kultúrát, az európai értékeket, ezért azt egy új szellemi-erkölcsi időszámítás kezdetének kell tekintenünk. Bár Spengler úgy vélte, hogy a nyugati civilizáció hanyatlási folyamata még több száz évig eltarthat, vele vitatkozva akár tarthatjuk a holokausztot e civilizáció végpontjának is. Azonban nyilvánvaló, hogy Kertész is része annak a kultúrának, amit néhol folytathatatlannak vél, Auschwitz traumáját megragadni próbáló alkotásai sok tekintetben illeszkednek a nyugati kulturális hagyományba (Nietzsche, Thomas Mann, Kafka, Camus és még sok más európai alkotó hatása kimutatható a művein). Ö maga is elismeri A számüzött nyelvben, hogy a német kultúra meghatározó befolyással volt rá, és így „a borzalmat, amit Németország zúdított a világra, ötven évvel később némileg a német kultúra eszközeivel formáltam meg és adtam vissza müvészetként a németeknek" (Kertész 2001a, 294). Kertész a civilizációs megújulásra lát némi reményt: ahhoz, hogy Auschwitz ne ismétlődhessen meg, a holokausztnak kultúrává kellene válnia. Az író azonban nem fejti ki részletesen, hogy mit is jelent a holokauszt mint kultúra, ez leginkább egy, a holokauszt tapasztalatára alapozott morális közösségként értelmezhetö. Kertész a holokausztról mint kultúráról írva mintha német felfogás szerint megkülönböztetné a civilizáci- 
ót (amely valamilyen „külsődlegességet” jelent, technikát, tudományt, illemszabályokat) és a kultúrát (művészet, vallás, filozófia, Kant szerint a moralitás eszméje is a kultúrához tartozik) ${ }^{52}$ és arra utalna, hogy a kultúrának kellene átalakítania a civilizációt (ez Spengler elmélete szerint lehetetlen, de Thomas Mann-nál és más szerzőknél találhatunk hasonló gondolatokat), vagy szükséges volna kulturális alapokon létrehozni egy új civilizációt. Persze, a holokauszt mint kultúra esélyeit illetően Kertész is megfogalmaz kételyeket, hiszen a reális életben ennek nem nagyon látni a nyomait, ugyanakkor - véli Kertész - „a fontos események nem mindig tükröződnek az egyidejü közvetlen realitásban" (Kertész 2001a, 91).

\section{Irodalom}

Barcsi Tamás. 2018. A kudarc lehetősége: Kertész Imre műveiről erkölcsfilozófiai szempontból. Partitúra (2): 23-68.

Csejtei Dezső-Juhász Anikó. 2009. Oswald Spengler élete és filozófiája. Máriabesnyő-Gödöllö: Attraktor.

Cs. Szabó László. 1937a. Búcsú a vándorévektől. In Levelek a számüzetésböl. 15-33. Budapest: Franklin Társulat.

Cs. Szabó László. 1937b. Müfaj és nemzedék. In Levelek a számüzetésböl. 86-95. Budapest: Franklin Társulat.

Kakuszi B. Péter. 2001. Márai Sándor és Németország. Pécs: Pro Pannonia.

Kertész Imre. 1997. Valaki más. Budapest: Magvető.

Kertész Imre. 2001a. A számüzött nyelv. Budapest: Magvetö.

Kertész Imre. 2001b. Gályanapló. Budapest: Magvető.

Kertész Imre. 2002a. Sorstalanság. Budapest: Magvető.

Kertész Imre. 2002b. Kaddis a meg nem született gyermekért. Budapest: Magvető.

Kertész Imre. 2016. A néző. Budapest: Magvetö.

Kertész Imre. 2017. A végső kocsma. Budapest: Magvető.

Lőrinczy Huba. 1997. Egy spengleriánus nyugati Keleten: Istenek nyomában In Ambrustól Máraihoz: Válogatott esszék, tanulmányok. 267-281. Szombathely: Savaria University Press.

Margittai Gábor. 2005. Nyugtalan klasszikusok: Ars Poeticák és arcpoétikák - Hagyománytudat Babits Mihály esszémüvészetében. Máriabesnyő-Gödöllö: Attraktor.

Márai Sándor. 1945. Napló 1943-1944. Budapest: Helikon.

Márai Sándor. 1992. Ihlet és nemzedék. Budapest: Akadémiai-Helikon.

\footnotetext{
${ }^{52}$ A kultúra és a civilizáció értelmezéstörténtéről (német nyelvterületen) lásd Csejtei-Juhász 2009, 137-145.
} 
Márai Sándor. 2000. Kassai őrjárat. Budapest: Helikon.

Márai Sándor. 2004a. Egy polgár vallomásai. Budapest: Európa.

Márai Sándor. 2004b. Napnyugati őrjárat. Budapest: Helikon.

Márai Sándor. 2006a. A teljes napló: 1945. Budapest: Helikon.

Márai Sándor. 2006b. Föld, föld!... Budapest: Helikon.

Márai Sándor. 2006c. Vasárnapi krónika. Budapest: Helikon.

Márai Sándor. 2008. Európa elrablása: Röpirat a nemzetnevelés ügyében. Budapest: Helikon.

Márai Sándor. 2011. Istenek nyomában. Budapest: Helikon.

Spengler, Oswald. 2011. A Nyugat alkonya: A világtörténelem morfológiájának körvonalai.

I. Ford. Csejtei Dezső-Juhász Anikó. II. Ford. Simon Ferenc. Budapest: Noran Libro.

Spengler, Oswald. 2013a. Poroszság és szocializmus. In Válságok árnyékában. Ford. Csejtei Dezső-Juhász Anikó. 9-105. Budapest: Noran Libro.

Spengler, Oswald. 2013a. A döntés évei: Németország és a világtörténelmi fejlödés. In Válságok árnyékában. Ford. Csejtei Dezső-Juhász Anikó. 155-325. Budapest: Noran Libro.

Szabó Zoltán. 2001. Vigasztalásul útnak indulunk...: Magyar útirajzok. In Németh László. 2001. Magyarok Romániában: Az útirajz és a vita. 241-248. Marosvásárhely: Mentor.

Szávai János. 2008. A kassai dóm: Közelítések Márai Sándorhoz. Pozsony: Kalligram.

Szerb Antal. [2000]. A világirodalom története. Budapest: Magvetö.

Thienemann Tivadar. 1922. A Nyugat alkonya: Oswald Spengler és a Spengler-irodalom. Minerva 1 (8-10): 342-361.

White, Hayden. 1973. Metahistory: The Historical Imagination in Nineteenth-Century Europe. Baltimore: Johns Hopkins University Press.

\section{Tamaš BARČI-Akoš NEMET \\ UTICAJ OSVALDA ŠPENGLERA NA INTERPRETACIJE CIVILIZACIJE U DELIMA ŠANDORA MARAIJA I IMREA KERTESA}

U ovom radu istražujemo kako su kulturne i civilizacijske interpretacije Osvalda Špenglera uticale na misao dvojice značajnih mađarskih autora, Šandora Maraija i Imrea Kertesa. Prvo predstavljamo u kojoj meri je Špenglerov uticaj uočljiv u Maraijevim delima pisanim u različitim periodima. U čemu se Marai slaže sa Špenglerom a gde im se razilaze mišljenja? Potom razmatramo zaključke u konzervativizmu Imrea Kertesa koji se mogu porediti sa interpretacijama koje Špengler iznosi u Propasti Zapada. Na kraju govorimo o sličnostima i razlikama između interpretacija civilizacije u delima Maraija i Kertesa.

Ključne reči: Šandor Marai, Imre Kertes, Osvald Špengler, civili 
Tamás BARCSI-Ákos NÉMETH

\section{THE INFLUENCE OF OSWALD SPENGLER ON THE CIVILIZATION INTERPRETATIONS OF SÁNDOR MÁRAI AND IMRE KERTÉSZ}

In our study we examine how the culture and civilization interpretation of Oswald Spengler influenced the thought of two significant Hungarian authors, Sándor Márai and Imre Kertész. We first present to what extent the Spengler-effect is detectible in the works of Márai written in various periods. Where does Márai agree with Spengler and where does he argue with him? After this we discuss the conclusions in the conservatism of Imre Kertész that may be paralleled with the interpretation explained by Spengler in The Decline of the West. Finally, we write about the similarities and differences between the civilization interpretation of Márai and Kertész.

Keywords: Sándor Márai, Imre Kertész, Oswald Spengler, civilization 